\title{
A NEW APPROACH THAT PROPOSES TRIZ AS A CREATIVE PROBLEM SOLVING TECHNIQUE IN HEALTH SERVICES
}

DOI: 10.17261/Pressacademia.2020.1200

RJBM-V.7-ISS.2-2020(2)-p.67-79

Seyma Guner ${ }^{1}$, Ilker Kose ${ }^{2}$

${ }^{1}$ Istanbul Medipol University, Department of Management and Strategy, Istanbul, Turkey. sguner@medipol.edu.tr, ORCID: 0000-0002-9591-9276

${ }^{2}$ Istanbul Medipol University, Department of Health System Engineering, Istanbul, Turkey. ikose@medipol.edu.tr, ORCID: 0000-0002-5549-5579

Date Received: March 3, 2020

Date Accepted: June 2, 2020

To cite this document

Guner,S., Kose, I., (2020). A new approach that proposes TRIZ as a creative problem solving technique in health services. Research Journal of Business and Management (RJBM), V.7(2), p.67-79.

Permanent link to this document: http://doi.org/10.17261/Pressacademia.2020.1200

Copyright: Published by PressAcademia and limited licensed re-use rights only.

\begin{abstract}
Purpose- The aim of this study is to produce a new solution matrix to develop innovative solutions for the problems encountered during the delivery of health services and to present a methodology on how to use TRIZ in health services.

Methodology- In this study, contradiction matrix, 40 principles and IFR-idealism philosophy, which are among the basic TRIZ paradigms, were used in the process of presenting innovative solutions. One of the Pairwise Comparison methods AHP (Analytical hierarchy process) was used when parameter matching.

Findings- As a result of the study, a new matrix and methodology has been developed.

Conclusion- Although TRIZ is a very famous problem-solving method, there are only a few studies that use TRIZ to improve service quality in healthcare. This study proposes a new framework for TRIZ's use in healthcare and will serve as a guide for researchers working in this field. Healthcare providers will be able to develop innovative solutions to the problems they encounter by using the $16 \times 16$ solution matrix developed as a result of this study and following the methodology proposed as a result of this study.
\end{abstract}

Keywords: TRIZ, contradiction matrix, innovation management, quality in health services

JEL Codes: I19, L21, M10

\section{INTRODUCTION}

Companies are trying to produce new ideas and develop creative solutions to their problems by using various methods. While other creative thinking techniques, such as brainstorming, lateral thinking and SCAMMER technique are planned to solve the intellectual inertia, the TRIZ offers solutions based on contradictions to the problems. Although it has high acceptance in the technical domain, TRIZ is not so prevalent in the service domain. This study proposes a novel solution matrix (one of the TRIZ methods) by matching the contradiction matrix with the quality parameters of the service sector (here, the healthcare sector) and presents a methodology on how to use TRIZ in the service domain. In this study, firstly, we matched the health service quality criteria and the parameters (which are the columns and lines of the TRIZ's contradiction matrix) by using binary comparison method and the 16x16 matrix was obtained. Then, we applied the brainstorming method to gather the problems and selected the technical ones. During the solution of these problems, their improving and deteriorating features were found so that we determined their appropriate cell in the $16 \times 16$ matrix. The methods that solve our problem have been determined by taking into consideration the TRIZ solution principles that correspond to these cells and are located in the cells of the original $39 \times 39$ contradiction matrix of TRIZ. By showing that the problems in our problem pool can be solved, we suggested that the proposed 16x16 matrix can be used in the service sector in general and the health service sector in particular. This study is one of the few studies in the literature using TRIZ in the service sector. By following the proposed methodology, the health service providers will 
be able to gather and eliminate the problems, and then generate innovative solutions for the technical ones. The contradiction matrix that is proposed in this study will be a good starting point for researchers to obtain a better solution for the service sector with further studies.

Our article consists of four parts; In order to emphasize the importance and benefits of the TRIZ method, which is the subject of our study in the literature review section, previous studies are included and comparisons of the methods commonly used in quality improvement in the service sector are presented. In the following, the data collection and matrix development stages of our study are given in detail and the methods applied are explained; In the last section, the results are discussed and inferences are made and ideas are presented about the future studies.

\section{LITERATURE REVIEW}

\subsection{TRIZ}

The abbreviation TRIZ consists of the initials of the words "Teoriya Resheniya Izobreatatelskikh Zadatch" (Creative Problem Solving Theory), which is referred to as "теория решения изобретательских задач" in Russian. It is creative problem-solving techniques that were developed by Genrich Saulovich Altshuller, who was an engineer and worked as a patent officer in the Soviet Union in 1946 (Genrikh Saulovich Altshuller, 1984). Altshuller, who is known as the father of TRIZ methods, realized that in the patent applications he studied while working as a patent specialist, the idea put forward as a new invention, was formed as a result of repeating basically similar main themes with different names in different fields and started to investigate patents (Salamatov, 1999). In his study on more than 200.000 patent applications, he proved that there are 1500 technical contradictions that can be solved by applying basic principles (Pala and Srikant, 2005). He observed that only 40,000 of the patents he examined had creative solutions, while the rest appeared as a result of repeating previously existing ideas or inventions in different fields of application. As a result of the 2.5 million patents it has examined, it has been shown that a problem encountered in one sector and a lot of time and money spent on its solution is basically similar to the problems encountered in another sector. Generalizing the principles on which the inventions are based, we have made 39 parameters by generalizing them for the use of each sector and created a problem solving matrix from these parameters. Another point that attracted the attention of Altshuller as a result of the studies he examined; The proposed methods for the solution of the problems are a new problem and this situation contains contradictions. In short, each idea presented as a new solution has another problem. each solution creates its problem. The important thing is to be able to predict the results of the reaction that may occur against the action effect and to prepare solution measures accordingly. This is one of the most important features of TRIZ that distinguishes it from other creative problem solving techniques. TRIZ detects contradictory situations in problems and offers solutions to these problems through contradictory. For example; We want the table we produce to be strong, but the materials we use to ensure this stability cause the table we produce to be heavy and it is undesirable to have the table heavy. As another example; We want to reduce their workloads to increase personnel efficiency, and if we consider recruiting new personnel to provide this situation as a solution, this causes an unwanted situation such as cost. As can be seen from the examples that can be increased further, it is very difficult to produce an absolute beneficial solution method, each solution proposal reveals its contradictory situations. TRIZ, on the other hand, offers systematic solution suggestions over contradictory situations. TRIZ does not decide instead of decision maker, it guides the decision maker. Although these methods are mostly used for solving problems in technical fields, TRIZ parameters and principles are used in social and commercial fields such as non-technical policy, politics, marketing, and business management in recent years (Altuntaş Serkan and Yener, 2012). Thanks to the systematic solution offer offered by TRIZ, anyone who receives this training can produce effective innovative solutions in their field.

\subsubsection{Basic TRIZ Tools and Methods}

TRIZ is not a single method, it is a collection of methods that contains many methods and to generate systematic ideas (Chechurin and Borgianni, 2016)). While some of the TRIZ methods are aimed at solving existing problems, some of them are about the future. Although there are many books and articles about TRIZ today, there is no publication where all TRIZ methods are collected and included. Although Altshuller, the creator and developer of TRIZ, presented TRIZ methods in his publication "About A Technology of Creativity" published with Shapiro, all methods are not included because of today's TRIZ methods are not included in that source (G.S. Altshuller and Shapiro, 1956). According to Valeri, it is very difficult to collect all the methods of modern TRIZ in a single book. Ilevbare et al. (Ilevbare, Probert and Phaal, 2013) He sent a survey to $40 \mathrm{TRIZ}$ experts around the world to measure the use of TRIZ in practice. According to the survey results; the most common TRIZ method is "40 Inventive Principles". The frequency of use of TRIZ tools is given below (Figure 1). 
Figure 1: Frequency of Use of Agricultural Tools According to the Survey Results (Ilevbare et al., 2013)

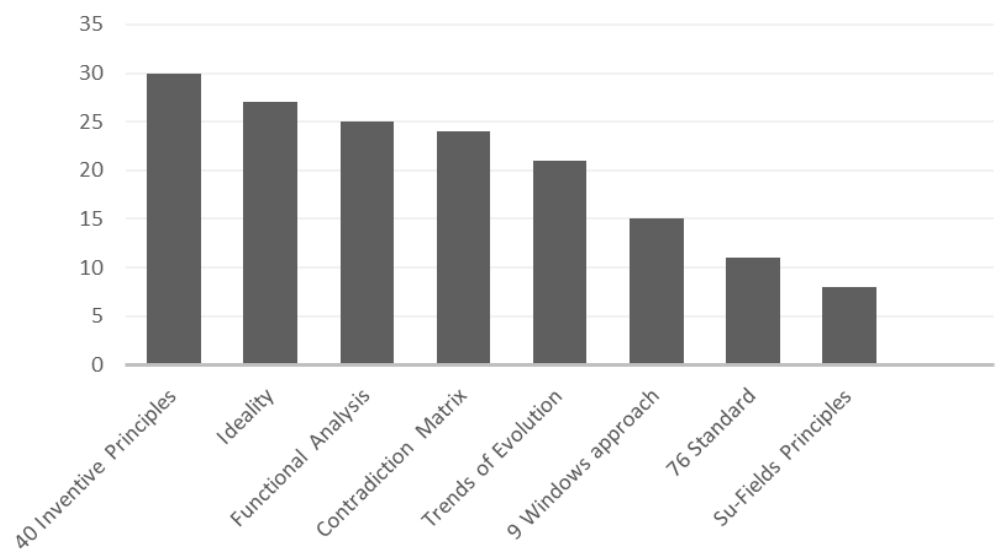

If we examine the data in Figure 1 as a percentage (\%), we reach the results in Table 1 . According to these rates, more than $70 \%$ of TRIZ users use the principles of the invention and ideal, while $50-69 \%$ use the function analysis and contradiction matrix in creative problem solving.

Table 1: Percentage of Use of TRIZ Methods

\begin{tabular}{|l|l|}
\hline TRIZ Users\% & TRIZ Tools \\
\hline$>\% 70$ & $\begin{array}{l}\text { 40 Principle of Invention } \\
\text { Principle of Ideality }\end{array}$ \\
\hline$\% 50-\% 69$ & $\begin{array}{l}\text { Function Analysis } \\
39 X 39 \text { Conflict Matrix }\end{array}$ \\
\hline$<\% 50$ & $\begin{array}{l}9 \text { Window Approach } \\
76 \text { Standard } \\
\\
\text { Su-Field Analysis } \\
\text { ARIZ }\end{array}$ \\
\hline
\end{tabular}

In the later stages of our study, "40 Inventive Principles", "39X39 Contradiction Matrix" and "Ideality" methods were used.

\subsection{Sectors Benefiting from TRIZ}

In an ever-evolving and changing global world, businesses aim to continue their existence and gain superiority in competition. In order to achieve these goals, they have to meet customer expectations and even provide products or services that exceed expectations. In order to meet the expectations of customers who expect low cost and high quality of the products or services they receive, businesses are required to design their business processes close to perfection, to follow innovations, and to provide high quality products and services by quickly finding solutions to their problems. Considering these objectives of companies, TRIZ feature, which emphasizes creativity and innovation, is thought to be a necessary method for companies to produce high quality and low cost ideal products or services (Şener, 2006).

Nowadays, many big companies that are aware of the advantages of TRIZ in practice now give TRIZ training to their employees in recruitment and wait for their implementation in business processes (Kaya, 2017). The effectiveness and benefits of TRIZ method in practice have been demonstrated by many studies (Altuntaş Serkan and Yener, 2012; Chechurin, 2016; Durgun and Doruk, 2015; Fiorineschi, Frillici, and Rotini, 2018; LariSemnani, Mohebbi Far, Shalipoor and Mohseni, 2015; Li, Atherton and Harrison, 2014; Mishra, 2013). Although TRIZ methodology has been applied with different plugins in different sectors, its use in the service sector is not common compared to other sectors (Ilevbare et al., 2013). In 2013, they asked 40 TRIZ professionals around the world in which areas they benefited from TRIZ to measure the use of TRIZ. While $85 \%$ of TRIZ professionals stated that they implemented TRIZ in technology, only $24 \%$ stated that they used TRIZ in areas requiring management and strategy (Figure 2). 
Figure 2: The areas where TRIZ is used most frequently (Ilevbare et al., 2013)

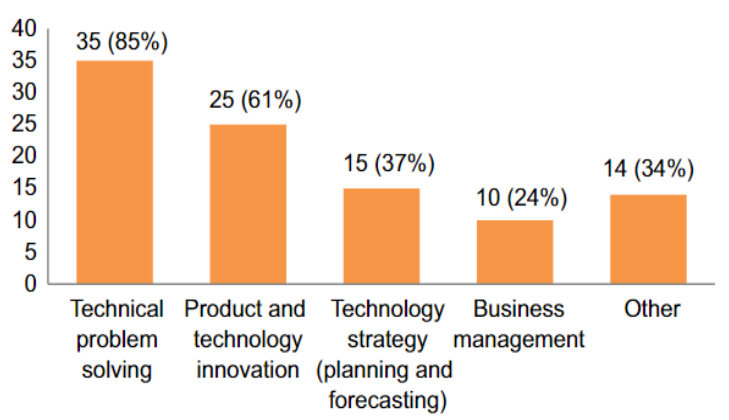

\subsection{Quality in Health Services Sector}

The concept of quality comes from the Latin word "quality" which is translated as "how it was formed". As it is understood from this meaning, quality is used to determine how and how a product or service occurs. Quality is a dynamic process. In other words, a product or service called quality today may be considered poor quality in the future. In this respect, quality can also be defined as suitability in time (Duran, 2011). Quality, which is open to continuous improvement, includes the goal of exceeding these expectations beyond meeting customer needs and expectations (Çelik, 2018). The concept of quality; "It is used to express the difference, suitability and usability of the product or service that changes and develops over time (Gürbüz, 2014). The main goal of the enterprises is to meet the expectations of the service they provide to the customer and even exceed this expectation.

The most important feature of the healthcare sector that distinguishes it from other service sectors is that a possible mistake can cause an inability to work, to spend the remaining life of the patient in poor quality and even to the loss of human life. Working with 'zero error', which is one of the basic principles of the concept of quality, is much more important in the health sector. For all these reasons, the concept of quality service becomes more and more specialized in the healthcare sector. Problem solving and innovation management methods play an important role in improving the quality of health. For this reason, almost every method developed in business science has been applied in health institutions that offer a very complex and information-intensive service in a short time, and sometimes these methods have been adapted to the special needs of health institutions.

\subsubsection{Problem Solving Methods Used in Quality Studies in Health}

\subsubsection{Lean Hospital and Healthcare Quality}

Lean management model "How do we realize the cheapest and error-free production with the least resources, in the shortest time possible, with the least amount of waste and the most flexible use of all production factors, to respond to customer demand? "It is a process improvement model that emerged as a result of the answer to the question (Aytaç, 2009). The lean management approach includes labor, equipment, time, etc. it adopts to avoid waste of any kind by including waste of resources, to eliminate works without added value or to minimize the resources spent for these jobs and to design a new process in which resources are directed to jobs that will create more value (Shannon et al., 2006). The first use of the lean management model in health services dates back to the 2000s. For the first time in American health care system in England and applied lean hospital model was introduced in Turkey in recent years. In addition to its new use in the health system of our country, it is becoming more and more widespread (ilkim and Derin, 2016). The digitalization of the health system in various fields such as requesting tests online, switching to an electronic system in prescriptions, electronic appointment system can be seen as the macro-sized applications of lean management in the health system. Simple and macro-level lean practices are used in various subjects such as preventing the increasing costs in health, ensuring patient and personnel satisfaction, preventing waste, and increasing the quality of service provision (Güleryüz, 2012). The activities that do not add value to the treatment process of the patient are determined and the resources spent on these activities are transferred to other activities that are expected to provide added value.

\subsubsection{6 Sigma and Quality in Health}

The 6 Sigma approach is a strategic quality improvement method designed by a US company that wants to gain an advantage in competition against Japanese products in 1985 (Bircan and Köse, 2012). This method first emerged as tools and techniques 
designed to detect and eliminate errors encountered in production processes and work with high efficiency. After its effectiveness was noticed and developed, it became a method used in non-production processes by using it in various fields such as business, bank and insurance (Şener, 2006). The basis of this approach is to ensure customer satisfaction by increasing quality. In statistics, sigma represents distance from the mean (standard deviation), while 6 Sigma represents below average deviation (Şener, 2006). Aiming for perfection, this method allows only 3.4 errors per million.

3.4 million per million error, which is the statistical equivalent of the 6 Sigma approach, means that the company that adopts this approach works close to zero error. The information that a business is operating with a $1 \%$ error may be perceived as a low rate in the first place, but the low or high number of errors varies according to the field of the business. For example, in a health institution where 400 operations are performed per day, the knowledge that it works with a $1 \%$ error rate means that 4 patients die every day. Health institutions should work with "zero error". That the quality of processes in health institutions is at 6 Sigma level means that the error rate is close to zero. Although the practices of this approach in the health sector are later than other sectors, in recent years, many institutions have been using the 6 Sigma method to improve the quality of health services. 6 Sigma application in health sector; It is used in many areas such as reducing the length of hospital stay of patients, detecting and correcting errors during invoicing, errors in drug use, correction in payment periods, improving quality, ensuring personnel efficiency, organizing patients. It is aimed to reduce the error rates and increase the quality in this way (Bircan and Köse, 2012; Coskun, Unsal, Serteser and Inal, 2010; Deniz, Staub and Çimen, 2016; Kuşçu et al., 2018; Özveri and Çakır, 2012; Yıldız, 2018).

\subsubsection{Use of TRIZ in Health Care Services}

Methods such as six sigma, lean hospital are used more frequently in quality improvement studies in health services. When the literature is analyzed, only 3 publications using TRIZ were found in quality improvement studies in health services (Altuntaş Serkan \& Yener, 2012; LariSemnani et al., 2015; Lin, Chen, \& Chen, 2012). In these studies, they took a result-oriented approach instead of a method proposal and did not offer a fully functional matrix proposal. Few studies have focused on improving TRIZ healthcare quality. These studies are given below.

In the study of Shu-Ping et al. In 2012 (Lin et al., 2012), TRIZ parameters using the model proposed by Parasuraman (Parasuraman, Zeithaml, \& Berry, 1985) and their friends to determine the themes to be improved in the service industry. They aimed to develop a new matrix by matching with. It is not mentioned in detail in the study what this matching is made or how it is tested. While doing this matching, they could not offer a complete matrix suggestion because they match some parameters with 1 and 2 with TRIZ parameters. In addition, they tried to develop a solution proposal by interpreting the 40 principles directed by their matching, not problem specific but in general. The basic usage principle of TRIZ is to place each problem into parameters by placing it in the TRIZ matrix and trying to improve it by examining the solution suggestions offered by the matrix in the intersection cell.

In another study conducted in 2015 (LariSemnani et al., 2015), they tried to use the TRIZ model to develop the necessary strategies to improve the quality of the services provided to patients. In fact, this study shows what is the priority in the quality aspect of care provided to patients. For this purpose, they used a survey method to collect information and applied surveys to 96 people in total. Service quality; they addressed in 5 dimensions: empathy, assurance, reliability, responsiveness and physical assets. A $31 \mathrm{x}$ 31 matrix known as WIN-WIN was used to solve management problems with TRIZ. He measured the perceived and expected service quality for all 5 dimensions and reached the conclusion that the most deficit was seen in the "empathy" dimension. Later, they expressed each of these dimensions as a problem and placed them in the matrix and tried to provide general suggestions. But these solution suggestions do not improve once the problem is identified, but After determining the size, it is presented as general solution suggestions. They aimed to identify the 40 most repeated principles from the proposals of the TRIZ matrix. As a result of this study, it is not aimed to present a matrix or methodology proposal.

Also in another study conducted by Altuntaş and Yener (Altuntaş Serkan \& Yener, 2012) in 2012; 10 service quality dimensions proposed by Parasuraman were discussed. These 10 service quality were matched with TRIZ parameters and 10 experts were asked whether they participated in this matching. Since 2 matches were not approved by half of the experts, they were discarded and a new matrix was introduced with the remaining 8 matches. However, in this study, it was not based on an explanation of what they did in the first match, and the experts were asked only their opinions against "1" matching. In this study, if more than 1 parameter was presented to the experts for each match, it is thought that a TRIZ parameter could be found for 2 dimensions excluded, thus the matrix could be more extensive. 


\section{DATA AND METHODOLOGY}

This study was designed based on the question of how TRIZ method, which is frequently used in other sectors and has very beneficial results, can be used in health services. The final result we want to achieve is to propose a unique methodology and to develop a matrix suitable for use in the service industry. While doing this, efforts have been made to catch the method that TRIZ followed in the beginning. Our limit condition here is that we do not have too many problems. In this process, group decisionmaking methods and creative thinking techniques were used in appropriate places within our framework. The methodology that has emerged and suggested accordingly is given in Figure-3 below. Our work, which tries to identify the problems experienced in health services and to offer creative solutions to the detected problems, consists of 11 steps. While determining these steps, the methods in a case study conducted in 2008 to improve the quality of the e-commerce company were reviewed for improvement (Su, Lin and Chiang, 2008).

\section{Figure 3: Implementation Steps of the Study}

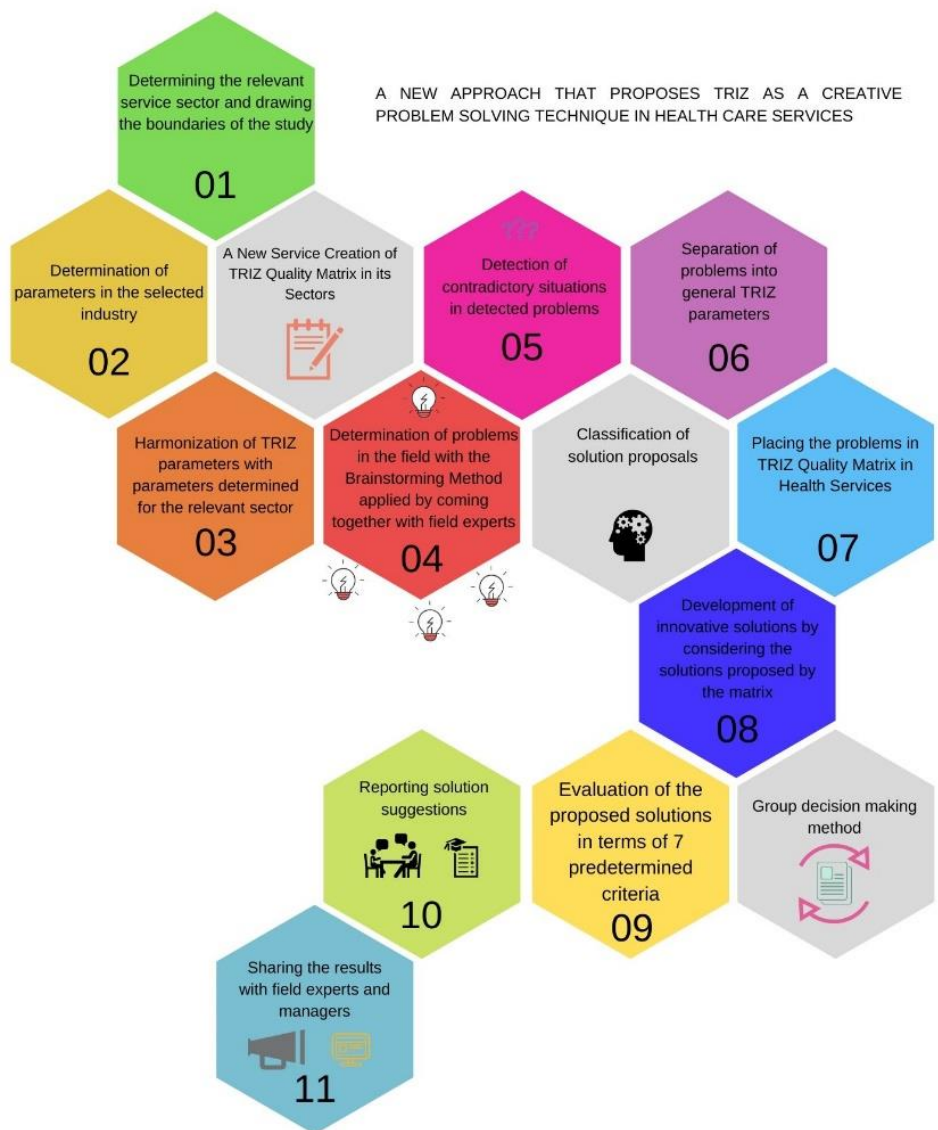

The objectives of the research are:

- To develop TRIZ matrix specific to the service sector,

- To develop a problem-solving methodology to identify problems and guide them through the TRIZ method,

- To test the methodology and functionality of the matrix with the studies to be carried out in a health institution. 
- To provide solutions to these problems detected in the health institution together with the field experts with the activities to be carried out with TRIZ.

\subsection{Selection of the Sector in Which the Study is Made and Determination of Areas and Dimensions in the Selected Sector}

As the first step in this study; The sector to be included in the study is determined as "Health Services Sector". Afterwards, it is aimed to identify the areas that are planned to be improved in health services. Since improvement is planned in the field of "Quality in Health Services", a comprehensive literature study has been carried out to determine the quality dimensions in the service sector. When we examine the studies in the literature; it has been observed that different methods such as SERVQUAL and SERPERF, Gaps model, data attenuation analysis, critical event method and service barometer are used as the quality measurement model in the service sector (Tanrıyar, 2017). As a result of the researches, since the quality of service is considered in the model proposed by Parasuraman and his friends, the 10 parameters proposed by Parasuraman and his colleagues are planned to be handled in this study to make the study more comprehensive (Parasuraman et al., 1985). SERVQUAL scale is a widely accepted service quality measurement model developed in 1985 by Parasuraman et al. 10 quality parameters recommended by Parasuraman and friends; reliability, responsiveness, competence-competence, access, respect-courtesy, communication, credibility, security, empathy and physical assets.

\subsection{Matrix Development}

Although the parameters of TRIZ's 39x39 Conflict matrix are wide-ranging and suitable for use in all disciplines, the field they initially associate with is technical issues. A few of these parameters (For example, the use of composite materials) are quite difficult to encounter in the healthcare industry, which is the subject of our study. It is aimed to develop a new "TRIZ Quality Matrix in Service Sectors" to provide ease of use and guide people who will perform quality improvement work in the service sector. The purpose of developing the matrix; The determination of TRIZ parameters corresponding to 10 quality parameters (Parasuraman et al., 1985) recommended in the literature and accepted in the literature. In this way, a new matrix special to the service sector will be presented. During this determination, it is expected from the participating experts to determine which TRIZ parameter covers and meets the relevant quality parameter more. The scope of the parameters is well understood in accordance with the problem literature examples examined during the comprehensive literature review and TRIZ trainings. Thanks to this information history, screening was made considering which of the 39 parameters presented by the conflict matrix could correspond to the quality parameters. As a result of this elimination, minimum 3 and maximum 11 TRIZ parameters, which are considered to correspond to each quality parameter, were determined. While determining the participants to be included in the matrix development studies; The criteria of being a university graduate at least undergraduate level and having at least 5 years of work experience in the sector or having graduated from relevant management departments at the graduate level are taken into consideration. Comparisons to a total of 9 experts who met these criteria were presented with descriptions of each parameter. The participants were asked to score the table sent to them according to the multi-criteria decision making method. Multi-criteria decision making methods allow decision makers to evaluate the data more analytically and evaluate alternative options by taking many criteria into account (Kocakaya, 2009).

1.The pairwise comparison-AHP (Analytical Hierarchy Process) [Pairwise Comparison (Saaty, 2000)] matrix was prepared and the participants were expected to compare the parameters by sharing with the participants as an excel file (a total of 90 tables were formed as the comparisons of the 9 experts were evaluated for 10 parameters).

The steps after this stage were applied separately for each "quality parameter" through the evaluated comparison tables from the participants.

2.Geometric averages were calculated for binary comparison matrices of matrix filled by each specialist and then power weights were calculated for each comparison. It is normalized by dividing the values in each cell in the matrix by the column total.

3.The arithmetic mean of each line in the normalized matrix is calculated by weight. The results obtained here show the importance of weights for each criterion.

The consistency of the comparison between the criteria shows the accuracy of the result. For this reason, a consistency analysis was performed to determine whether the results of the comparisons were collected analytically consistently. The consistency rate (CR) is calculated by a formula developed by Saaty (Özkan, Kocaoğlu and Özkan, 2018; Saaty, 2000). 
These calculations were made on all decision matrix responses (90 tables) from 9 experts for each quality parameter with a total number of 10. Replies from each expert, rather than performing the same operations for each table separately; It has been calculated and placed in the Excel spreadsheet whose formulas have already been entered. After determining that the results of our decision matrices are consistent, the "weights" of the matches in each matrix (each matrix represents 1 quality parameter) was examined. The parameters to be included in the new matrix to be developed were determined according to the "parameter weights" resulting from the analysis of the decision matrices. The parameter with the highest weight was added to the table by matching. In evaluation matrices, there are TRIZ parameters whose weight is the same as the quality parameter. In this case, both parameters that have the same weight without being selected among the parameters are included in the matrix. As a result of these processes, "TRIZ Quality Matrix in Service Sectors" has been developed (Table 2).

Table 2: TRIZ Quality Matrix in Service Sectors (Guner, 2019)

\begin{tabular}{|c|c|c|c|c|c|c|c|c|c|c|c|c|c|c|c|c|}
\hline & 2 & 9 & 14 & 15 & 19 & 24 & 25 & 28 & 29 & 30 & 31 & 33 & 36 & 37 & 38 & 39 \\
\hline 2 & + & - & $28,2,10,27$ & - & - & $10,15,35$ & $10,20,35,26$ & $18,26,28$ & $10,1,35,17$ & $2,19,22,37$ & $35,22,1,39$ & $6,13,1,32$ & $1,10,26,39$ & $25,28,17,15$ & $2,26,35$ & $1,28,15,35$ \\
\hline 9 & - & + & $8,3,26,14$ & $3,19,35,5$ & $8,15,35,38$ & 13,26 & - & $28,32,1,24$ & $10,28,32,25$ & $1,28,35,23$ & $2,24,35,21$ & $32,28,13,12$ & $10,28,4,34$ & $3,34,27,16$ & 10,18 & . \\
\hline 14 & $40,26,27,1$ & $8,13,26,14$ & + & $27,3,26$ & $19,35,10$ & - & $29,3,28,10$ & $3,27,16$ & 3,27 & $18,35,37,1$ & $15,35,22,2$ & $32,40,25,2$ & $2,13,25,28$ & $27,3,15,40$ & 15 & $29,35,10,14$ \\
\hline 15 & - & $3,35,5$ & $27,3,10$ & + & $28,6,35,18$ & 10 & $20,10,28,18$ & 3 & $3,27,16,40$ & $22,15,33,28$ & $21,39,16,22$ & 12,27 & $10,4,29,15$ & $19,29,39,35$ & 6,1 & $35,17,14,19$ \\
\hline 19 & - & $8,15,35$ & $5,19,9,35$ & $28,35,6,18$ & + & - & $35,38,19,18$ & $3,1,32$ & - & $1,35,6,27$ & $2,35,6$ & 19,35 & $2,29,27,28$ & 35,38 & 32,2 & $12,28,35$ \\
\hline 24 & $10,35,5$ & 26,32 & - & 10 & - & + & $24,26,28,32$ & - & - & $22,10,1$ & $10,21,22$ & 27,22 & - & 35,33 & 35 & $13,23,15$ \\
\hline 25 & $10,20,26,5$ & - & $29,3,28,18$ & $20,10,28,18$ & $35,38,19,18$ & $24,26,28,32$ & + & $24,34,28,32$ & $24,26,28,18$ & $35,18,34$ & $35,22,18,39$ & $4,28,10,34$ & 6,29 & $18,28,32,10$ & $24,28,35,30$ & - \\
\hline 28 & $28,35,25,26$ & $28,13,32,24$ & $28,6,32$ & $28,6,32$ & $3,6,32$ & - & $24,34,28,32$ & + & - & $28,24,22,26$ & $3,33,39,10$ & $1,13,17,34$ & $27,35,10,34$ & $26,24,32,28$ & $28,2,10,34$ & $10,34,28,32$ \\
\hline 29 & $28,35,27,9$ & $10,28,32$ & 3,27 & $3,27,40$ & 32,2 & - & $32,26,28,18$ & - & + & $26,28,10,36$ & $4,17,34,26$ & $1,32,35,23$ & $26,2,18$ & - & $26,28,18,23$ & $10,18,32,39$ \\
\hline 30 & $2,22,13,24$ & $21,22,35,28$ & $18,35,37,1$ & $22,15,33,28$ & $1,24,6,27$ & $22,10,2$ & $35,18,34$ & $28,33,23,26$ & $26,28,10,18$ & + & - & $2,25,28,39$ & $22,19,29,40$ & $22,19,29,40$ & $33,3,34$ & $22,35,13,24$ \\
\hline 31 & $35,22,1,39$ & $35,28,3,23$ & $15,35,22,2$ & $15,22,33,31$ & $2,35,6$ & $10,21,29$ & 1,22 & $3,33,26$ & $4,17,34,26$ & - & + & - & $19,1,31$ & $2,21,27,1$ & 2 & $22,35,18,39$ \\
\hline 33 & $6,13,1,25$ & $18,13,34$ & $32,40,3,28$ & $29,3,8,25$ & $1,13,24$ & $4,10,27,22$ & $4,28,10,34$ & $25,13,2,34$ & $1,32,35,23$ & $2,25,28,39$ & - & + & $32,26,12,17$ & - & $1,34,12,3$ & $15,1,28$ \\
\hline 36 & $2,26,35,39$ & $34,10,28$ & $2,13,28$ & $10,4,28,15$ & $27,2,29,28$ & - & 6,29 & $2,26,10,34$ & $26,24,32$ & $22,19,29,40$ & 19,1 & $27,9,26,24$ & + & $15,10,37,28$ & $15,1,24$ & $12,17,28$ \\
\hline 37 & $6,13,28,1$ & $3,4,16,35$ & $27,3,15,28$ & $19,29,39,25$ & 35,38 & $35,33,27,22$ & $18,28,32,9$ & $26,24,32,28$ & - & $22,19,29,28$ & 2,21 & 2,5 & $15,10,37,28$ & + & 34,21 & 35,18 \\
\hline 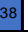 & $28,26,35,10$ & 28,1 & 25,13 & 6,9 & $2,32,13$ & 35,33 & $24,28,35,30$ & $28,26,10,34$ & $28,26,18,23$ & 2,33 & 2 & $1,12,34,3$ & $15,24,10$ & $34,27,25$ & + & $5,12,35,26$ \\
\hline 39 & $28,27,15,3$ & - & $29,28,10,18$ & $35,10,2,18$ & $35,10,38,19$ & $13,15,23$ & - & $1,10,34,28$ & $18,10,32,1$ & $22,35,13,24$ & $35,22,18,39$ & $1,28,7,10$ & $12,17,28,24$ & $35,18,27,2$ & $5,12,35,26$ & + \\
\hline
\end{tabular}

Table 3: Descriptions of the Parameters in the Row and Column of the Matrix

\begin{tabular}{|l|l|}
\hline 2- The weight of a stationary object & 29- Sensitivity of Production \\
\hline 9- Speed & 30- Harmful factors affecting an object from outside \\
\hline 14- Robustness & 31- Harmful elements created by the object \\
\hline 15- Action time-action time of a moving object & 33- Ease of Use \\
\hline 19- Energy consumed by a moving object & 36- Complexity of the System \\
\hline 24- Loss of Information & 37- Control complexity \\
\hline 25- Loss of Time & 38- Automation Level \\
\hline 28- Measurement Accuracy & 39-Capacity / Productivity \\
\hline
\end{tabular}

Table 4: Provisions of TRIZ 40 Principles in Matrix Cells

\begin{tabular}{|l|l|}
\hline $\mathbf{1}$ Segmentation & $\mathbf{2 1}$ Skipping \\
\hline $\mathbf{2}$ Taking Out/Separation & $\mathbf{2 2}$ 'Blessing in Disguise' \\
\hline $\mathbf{3}$ Local Quality & $\mathbf{2 3}$ Feedback \\
\hline $\mathbf{4}$ Asymmetry & $\mathbf{2 4}$ Intermediary \\
\hline $\mathbf{5}$ Merging & $\mathbf{2 5}$ Self-Service \\
\hline $\mathbf{6}$ Universality & $\mathbf{2 6}$ Copying \\
\hline
\end{tabular}




\begin{tabular}{|l|l|}
\hline $\mathbf{7}$ 'Nested Doll' & $\mathbf{2 7}$ Cheap Short-Living Objects \\
\hline $\mathbf{8}$ Anti-Weight & $\mathbf{2 8}$ Mechanics Substitution \\
\hline $\mathbf{9}$ Preliminary Anti-Action & $\mathbf{2 9}$ Pneumatics and Hydraulics \\
\hline $\mathbf{1 0}$ Preliminary Action & $\mathbf{3 0}$ Flexible Shells and Thin Films \\
\hline $\mathbf{1 1}$ Beforehand Cushioning & $\mathbf{3 1}$ Porous Materials \\
\hline $\mathbf{1 2}$ Equipotentiality & $\mathbf{3 2}$ Colour Changes \\
\hline $\mathbf{1 3}$ 'The Other Way Around' & $\mathbf{3 3}$ Homogeneity \\
\hline $\mathbf{1 4}$ Curvature & $\mathbf{3 4}$ Discarding And Recovering \\
\hline $\mathbf{1 5}$ Dynamization & $\mathbf{3 5}$ Parameter Changes \\
\hline $\mathbf{1 6}$ Partial or Excessive Actions & $\mathbf{3 6}$ Phase Transitions \\
\hline $\mathbf{1 7}$ Another Dimension & $\mathbf{3 7}$ Thermal Expansion \\
\hline $\mathbf{1 8}$ Mechanical Vibration & $\mathbf{3 8}$ Strong Oxidants \\
\hline $\mathbf{1 9}$ Periodic Action & $\mathbf{3 9}$ Inert Atmosphere \\
\hline $\mathbf{2 0}$ Continuity of Useful Action & $\mathbf{4 0}$ Composite Materials \\
\hline
\end{tabular}

\subsection{Identifying Problems in Areas to Improve}

After determining the relevant sector and the parameters in this field, problems in the sector were identified with the brainstorming method, which is accepted as the best known method to generate ideas (Isaksen and Gaulin, 2005; Jordan, 2010; Rawlinson, 2017).Before the brainstorming sessions, the participants were identified and some training was given to them after the scope, quality and objectives of the study were explained. They were asked to identify the problems they faced under the 10 recommended quality parameter heading.

\subsubsection{Identifying Participants}

In order to determine the health professionals to participate in the brainstorming study, information was obtained about the managers who can be included in the study by applying to the chief physician of a private health institution serving in Istanbul and the quality management unit. In the selection of the participants; The criteria of being a university graduate at least undergraduate level and having worked in the sector for at least 5 years are determined. Then, the scope of the study was explained by contacting the managers directed by the quality manager of the institution, and they were asked whether they could participate in this study voluntarily and 17 of the 32 managers interviewed were included in the study. Participants in the study consist of managers working in 13 different administrative units of the hospital. The average working time of the participants in the health sector is 17.3 years.

\subsubsection{Increasing the Knowledge Levels of Participants}

The managers within the scope of the study were given information about the quality parameters they have already applied (Table 5).

Table 5: Quality Parameters

\begin{tabular}{|l|l|}
\hline$\bullet$ Reliability & $\bullet$ Contact \\
\hline$\bullet$ Responsiveness & $\bullet$ Credibility \\
\hline$\bullet$ Competence & $\bullet$ Security \\
\hline$\bullet$ Access & $\bullet$ Empathy \\
\hline$\bullet$ Respect-Courtesy & $\bullet$ Physical Assets \\
\hline
\end{tabular}


A presentation was made about the reminder. In this presentation, examples about the scope of each parameter are presented. Then, to inform the participants about TRIZ, which we will use as a creative problem solving method, the training titled "Process Innovation in Healthcare Services with the Creative Problem Solving Technique TRIZ" was given.

These training were organized in two sessions in a meeting where all participants came together. Training resources were shared with the participants via e-mail and until the next meeting, they were asked to evaluate the problems they experienced in their business processes by considering the quality parameters and the TRIZ methodology.

\subsubsection{Gathering and Consolidating Ideas through Brainstorming Sessions}

In the idea collection phase of this study, the brainstorming method known as the most effective group idea generation method was applied to the participant group by adding different plugins (Bertoncelli, Mayer and Lynass, 2016; Isaksen and Gaulin, 2005; Sapuan, 2017). Advantage of brainstorming method in groups; during the brainstorming sessions of the individual, it is the opportunity for another friend in his group to read the idea that he has revealed and to create a new idea on it or to develop his existing idea.

The sessions were held with the participants divided into 2 groups accompanied by 2 moderators. While creating the groups, it was paid attention to the participants working in the same management unit to be in different groups. The event was held in a medium-sized meeting room to enable participants to create ideas in a comfortable environment, and a warm atmosphere was created and served to the participants.

As a result of the brainstorming session; $A$ total of 616 problems were identified. After these ideas were read by the moderators and brought together online and similar ones were combined, 149 discrete problems were identified.

\subsection{Placing the detected problems in the newly developed matrix and developing innovative solutions}

The contradictory situations of the problems detected in the brainstorming sessions were determined. After the conflicting situations of the problems were determined, they were matched with the general TRIZ parameters and placed on the "TRIZ Quality Matrix in Service Sectors" which was newly developed in this study. In the brainstorming sessions, the contradictory situations in the 10 problems we selected among the answers to the questions posed to the participants were identified and placed in the "TRIZ quality matrix in service sectors" that we developed and innovative solutions have been developed.

\subsection{Scoring and Evaluation of the Solution Offers Offered}

Managers were asked to rate the solution suggestions developed for the problems in terms of 7 criteria. In determining this criterion, it was developed based on 5 criteria used in the interactive innovation model proposal study presented to an internationally serving company (Kose, Guner, Isguzerer and Sisli, 2018).

These criteria are;

1. Additional Income Generating or Expense Reduction Potential

2. Indirect Benefits such as Marketing, Social Benefit, Awareness

3. Estimated time to be applied

4. Estimated project budget

5. It is innovation.

The criteria added apart from these criteria are;

6. Applicability

7. The project is the probability of encountering internal or external resistance.

After evaluating the solution suggestions within ourselves, the ratings of the solution suggestions were shared with the managers and their suggestions were included in the final evaluation stage. In the evaluation in the second stage, the IFR-Ideality ratios of the solution proposals were calculated. Thus, the solution suggestions were reevaluated and the most suitable solution methods were tried to be developed. 
Each criterion was evaluated as follows (high, medium, low, etc.). Since six criteria in total and 1 criterion in the denominator are included, the criteria results are scored as follows $(3,2,1,6,12,18)$. While calculating ideality, in some cases, time can be considered as a cost and included in the denominator. However, in our samples, it was not seen as a loss since it did not cause any loss cost.

Table 6: Evaluation Criteria

\begin{tabular}{|l|l|l|l|}
\hline Criteria 1 & $\bullet$ Much (3) & $\bullet$ Medium (2) & $\bullet$ Less (1) \\
\hline Criteria 2 & $\bullet$ Much (3) & $\bullet$ Medium (2) & $\bullet$ Less (1) \\
\hline Criteria 3 & $\bullet$ Long: 18+ Months (1) & $\bullet$ Medium: 6-18 Months (2) & $\bullet$ Short: 1-6 Months (3) \\
\hline Criteria 4 & $\bullet$ Many:> 500.000 TL (18) & $\bullet$ Medium: 500,000-100,000 TL (12) & Less: <100.000 TL (6) \\
\hline Criteria 5 & $\bullet$ Much (3) & $\bullet$ Medium (2) & $\bullet$ Less (1) \\
\hline Criteria 6 & $\bullet$ High (3) & $\bullet$ Medium (2) & $\bullet$ Low (1) \\
\hline Criteria 7 & $\bullet$ High (3) & $\bullet$ Medium (2) & $\bullet$ Low (1) \\
\hline
\end{tabular}

Table 7: Calculation of the Ideal Rates of Solution Proposals

\begin{tabular}{|c|c|c|c|c|c|c|c|l|}
\hline Solution no. & Criteria 1 & Criteria 2 & Criteria 3 & Criteria 4 & Criteria 5 & Criteria 6 & Criteria 7 & IFR Rate \\
\hline 1 & 3 & 3 & 2 & 3 & 3 & 2 & 12 & 1,33333 \\
\hline 2 & 3 & 3 & 3 & 2 & 3 & 1 & 6 & 2,5 \\
\hline 3 & 1 & 1 & 3 & 2 & 3 & 3 & 6 & 2,16667 \\
\hline 4 & 3 & 3 & 2 & 2 & 2 & 1 & 12 & 1,08333 \\
\hline 5 & 3 & 2 & 2 & 2 & 3 & 3 & 12 & 1,25 \\
\hline 6 & 2 & 3 & 2 & 2 & 3 & 3 & 6 & 2,5 \\
\hline 7 & 2 & 2 & 2 & 1 & 2 & 2 & 12 & 0,91667 \\
\hline 8 & 1 & 3 & 2 & 2 & 2 & 2 & 6 & 2 \\
\hline 9 & 1 & 3 & 2 & 2 & 2 & 1 & 12 & 0,91667 \\
\hline 10 & 1 & 2 & 3 & 1 & 3 & 3 & 6 & 2,16667 \\
\hline
\end{tabular}

According to the results obtained after evaluations by managers, the idealities of the solution suggestions were calculated. The Idea Account score table is given below (Table 7). According to IFR calculations, the most ideal solution suggestions are solution no. 2 and 6 . These suggestions are followed by suggestions 3, 10 and 8 . The managers of the relevant institution should consider these rates when deciding to implement their solutions.

The Idealness (IFR) calculation formula is as follows; Ideality $=\Sigma$ Benefits $/(\Sigma$ Cost $+\Sigma$ Loss $)$

\subsection{Sharing Results with Field Experts}

The result of the study and the proposed solution suggestions were reported to the senior managers of the relevant institution. In this report, besides the solution suggestions, the calculated IFR rates are also included. The creative solutions obtained as a result of the study were shared with the field experts at organized meetings.

\section{CONCLUSION}

Healthcare industry; It is a special case as it may cause loss of human life due to various reasons such as lack of health substitution, delay or not being able to receive the service. Health service providers have to continue to serve the problems they face by taking quick action. The fact that the person receiving service in health institutions working as a health business is individuals who doubt the health of their relatives or their relatives causes these people to be more nervous and to see the mistakes that may occur are unacceptable. Working with 'zero error', which is one of the basic principles of the concept of quality, is much more important in the health sector. For all these reasons, the concept of quality service becomes more and more specialized in the healthcare sector. Many methods such as lean hospital, Six Sigma are used to improve the quality during service delivery. This study is 
designed to evaluate and guide how TRIZ can be used for quality improvement in health care. And finally; proposes a new method to offer fast and innovative solutions to problems encountered during service delivery.

In order to test the functionality of the solution matrix and methodology we presented as a result of our study, we developed innovative solutions for the problems identified in the brainstorming session we did in the university hospital using this matrix and methodology. According to the results of the evaluation, it seems that we have obtained results that may correspond in practice. According to all these results, it has been seen that TRIZ methods and methodologies can also be used as a creative problem solving technique in health. It is recommended that health service providers include TRIZ methods in their quality improvement studies.

The functionality of the matrix and methodology developed as a result of the study was tested only on a limited number of problems obtained from a single health institution. Our limit condition here is that we have a small number of problem pools and we provide this problem pool with data in a single institution. Future studies can take into account the matrix we have developed through larger problem pools and the data of more organizations. In addition, the participation of industry experts in the problem solving phase can contribute to the creativity level of the solution proposals to be developed.

Financial project support was received from Medipol University Scientific Research Projects Commission. Ethics committee numbered 43037191-604.01.01-E.57707 was obtained from the Medipol University Ethics Committee Commission for the study.

\section{REFERENCES}

Altshuller, G. S. (1984). Creativity as an exact science : the theory of the solution of inventive problems ( translated from the R. by A. Williams., Ed.). New York: Gordon and Breach Science Publishers.

Altshuller, G. S., \& Shapiro, R. . (1956). About a technology of creativity. Questions of Psychology, 6, 37-49.

Altuntaş Serkan, \& Yener, E. (2012). An Approach Based on TRIZ Methodology and SERVQUAL Scale to Improve the Quality of Health-Care Service: A Case Study. Ege Akademik Bakış Dergisi, 12(1), 95-104.

Aytaç, Z. (2009). Hastanelerde Yalın Yönetim Sistemleri (Fen Bilimleri Enstitüsü). Retrieved from https://polen.itu.edu.tr/handle/11527/5717

Bertoncelli, T., Mayer, O., \& Lynass, M. (2016). Creativity, Learning Techniques and TRIZ. Procedia CIRP, 39, 191-196.

Bircan, H., \& Köse, S. (2012). Altı Sigma ve Firmaların Altı Sigmaya Bakış Açısı: Sivas-Kayseri İli Örneği. Ekonomik ve Sosyal Araştırmalar Dergisi, $8(2), 107-129$.

Chechurin, L. (2016). TRIZ in Science. Reviewing Indexed Publications. Procedia CIRP, 39, 156-165. https://doi.org/10.1016/j.procir.2016.01.182

Chechurin, L., \& Borgianni, Y. (2016). Understanding TRIZ Through The Review Of Top Cited Publications. Computers In Industry. Computers in Industry, 82, 119-134. https://doi.org/10.1016/j.compind.2016.06.002

Coskun, A., Unsal, I., Serteser, M., \& Inal, T. (2010). Six Sigma as a Quality Management Tool: Evaluation of Performance in Laboratory Medicine. In Quality Management and Six Sigma (p. 45). Sciyo.

Çelik, Ö. (2018). Hastanelerde Uygulanan Sağlıkta Kalite Standartlarının Sağlık Hizmet Kalitesi Üzerindeki Etkisinin Belirlenmesi: Konya Örneği. Selçuk Üniversitesi.

Deniz, S., Staub, S., \& Çimen, M. (2016). Altı Sigma Yaklaşımı ve Sağılık Sektöründen Başarı Örnekleri. Ankara: Nobel.

Duran. (2011). Yaratııı Problem Çözme Tekniği Yardımıyla Konstrüktif Bir Problemin Ele Alınması (Fen Bilimleri Enstitüsü). Retrieved from https://polen.itu.edu.tr/handle/11527/7898

Durgun, İ., \& Doruk, E. (2015). TRIZ Yaklaşımını Kullanrak ÖndenÇarpmalı Trafik Kazalarında Yayaların Güvenlik Koşullarının İyileştirilmesi. Afyon Kocatepe University Journal of Science and Engineering, 15, 1-6. https://doi.org/10.5578/fmbd.8307

Fiorineschi, L., Frillici, F. S., \& Rotini, F. (2018). Enhancing functional decomposition and morphology with TRIZ: Literature review. Computers in Industry, 94, 1-15. https://doi.org/10.1016/j.compind.2017.09.004

Guner, S. (2019). Sağlik Hizmetlerinde Yaratici Problem Çözme Tekniği Olarak Triz’i Öneren Yeni Bir Yaklaşim. İstanbul Medipol Üniversitesi.

Güleryüz, D. (2012). Yalın Yönetim Sistemlerinin Hastanelere Uyarlanabilirliği ve Bir Hastane Uygulaması. Sakarya Üniversitesi.

Gürbüz, F. (2014). Toplam Kalite Yönetimi Algısının Bireysel Performansa Etkileri Üzerine Sağlık Çalışanları Uygulaması. Ufuk Üniversitesi.

Ilevbare, I. M., Probert, D., \& Phaal, R. (2013). A review of TRIZ, and its benefits and challenges in practice. Technovation, 33(2-3), 30-37. 
https://doi.org/10.1016/J.TECHNOVATION.2012.11.003

Isaksen, S. G., \& Gaulin, J. P. (2005). A Reexamination of Brainstorming Research: Implications for Research and Practice. Gifted Child Quarterly, 49(4), 315-329. https://doi.org/10.1177/001698620504900405

İlkim, N. Ş., \& Derin, N. (2016). Dünyadan ve Türkiye'den Örneklerle Sağlık Hizmetlerinde Yalın Yönetim. Hacettepe Sağlık İdaresi Dergisi, 19(4), 465-479.

Jordan, R. M. (2010). Brain Storm. London: Harvard University Press.

Kaya, M. O. (2017). Dünya'da ve Türkiye'de Triz Kullanan Şirketler - kayam - Medium. Retrieved March 28, 2019, from medium website: https://medium.com/@metinokaya/dünyada-ve-türkiye-de-triz-kullanan-şirketler-52fb26beea8c

Kocakaya, Y. (2009). Tedarik Zinciri Yönetiminin AHP İle Çözüm Uygulaması: Analitik Hiyerarşi Süreci (AHP) Ille Otomotiv Sektöründe Yedek Parça Üreticisi Seçimi. Süleyman Demirel Üniversitesi.

Kose, I., Guner, S., Isguzerer, B., \& Sisli, M. E. (2018). A case study of the extended interactive innovation management model in insurance company. Proceedings of the European Conference on Innovation and Entrepreneurship, ECIE, 2018-Septe.

Kuşçu, F. N., Karaman, M., Karatepe, H. K., Alıcı, H., Yüce, U. Ö., \& Atik, D. (2018). Sağlık Kurumlarında Altı Sigma ve Toplam Kalite Yönetimi. Journal of Current Researches on Health Sector Article, 8(1), 125-135.

LariSemnani, B., Mohebbi Far, R., Shalipoor, E., \& Mohseni, M. (2015). Using Creative Problem Solving (TRIZ) in Improving the Quality of Hospital Services. Global Journal of Health Science, 7(1), 88-97.

Li, Z., Atherton, M., \& Harrison, D. (2014). Identifying patent conflicts: TRIZ-Led Patent Mapping. World Patent Information, $39,11-23$. https://doi.org/10.1016/j.wpi.2014.07.002

Lin, S.-P., Chen, C.-P., \& Chen, J.-S. (2012). Using TRIZ-Based Method To Improve Health Service Quality: A Case Study On Hospital. 2nd International Conference on Economics, Trade and Development, 62-66. IPEDR.

Mishra, U. (2013). Concept of Resources in TRIZ. Bangalore, India.

Özkan, H., Kocaoğlu, B., \& Özkan, M. (2018). Bir Eğitim Kurumunun Yemek Hizmeti Alımında Analitik Hiyerarşi Sürecine Göre Tedarikçi Seçimi. Uluslararası Sosyal Araştırmalar Dergisi / The Journal of International Social Research, 11(9), 1048-1062. https://doi.org/10.17719/jisr.2018.2715

Özveri, O., \& Çakır, E. (2012). Yalın Altı Sigma Ve Bir Uygulama. Afyon Kocatepe Üniversitesi İktisadi ve İdari Bilimler Fakültesi Dergisi, 14(2), 1736.

Pala, S., \& Srikant, A. (2005). Triz: A New Framework for Innovation: Concepts and Cases. Uttarancal: The ICFAI University Press.

Parasuraman, A., Zeithaml, V. A., \& Berry, L. L. (1985). A Conceptual Model of Service Quality and Its Implications for Future Research. Journal of Marketing, 49(4), 41-50.

Rawlinson, J. G. (2017). Creative Thinking and Brainstorming. New York, USA: Routledge.

Saaty, T. L. (2000). Fundamentals of Decision Making and Priority Theory With the Analytic-Analitik Hiyerarşi Süreci ile Karar Verme ve Öncelik Teorisinin Temelleri. New York: RWS yayınları.

Salamatov, Y. (1999). TRIZ: The Right Solution A The Right Time A Guide to Innovative Problem Solving (1st ed.; Valeri Souchkov, Ed.). Netherlands: Insytec BV.

Sapuan, S. M. (2017). Chapter 5:Conceptual Design Methods for Composites. In Conceptual Design in Concurrent Engineering for Composites (pp. 141-207). Elsevier Inc.

Shannon, R. P., Frndak, D., Grunden, N., Lloyd, J. C., Herbert, C., Patel, B., ... Spear, S. J. (2006). Using Real-Time Problem Solving to Eliminate Central Line Infections. The Joint Commission Journal on Quality and Patient Safety, 32(9), 479-487.

Su, C. T., Lin, C. Sen, \& Chiang, T. L. (2008). Systematic improvement in service quality through TRIZ methodology: An exploratory study. Total Quality Management and Business Excellence, 19(3), 223-243.

Şener, S. D. (2006). Trız: Yaratııı Problem Çözme Teorisi Ve Diğer Problem Çözme Yöntemleriyle Karşılaştırma (Fen Bilimleri Enstitüsü). Retrieved from https://polen.itu.edu.tr/handle/11527/3174

Tanriyar, i. (2017). Hizmette Kalite ve Servqual. Retrieved August 19, 2019, from AGDEM website: http://www.agdem.com/index.php?option=com_content\&view=article\&id=413\%3Ahzmette-kalte-ve-servqual\&catid=67\%3Alhantanriyar\&Itemid $=158$

Yıldız, M. S. (2018). Sağlıkta Kalite Bilgi ve Deneyim Düzeyinin Değerlendirilmesi: Türkiye ve Suudi Arabistan Hastaneleri Kalite. Dergipark.org.tr, 5(2), 188. 